\title{
11 A matter of gender (in)equality? Public discourses on declining fertility rates in Japan and Norway
}

Guro Korsnes Kristensen and Yukari Semba

\section{Declining fertility rates}

The stable production of healthy new generations is the most important resource of any collective of people, including the nation. Hence policy makers, experts and the general public pay close attention to the national fertility rates, ${ }^{1}$ expressing worries if they appear too high or low. This paper sets out to explore the triangle of fertility, nation and gender, focusing on the cultural meanings that are ascribed to the notion of declining fertility rates when this phenomenon is discussed publicly in Japan and Norway.

In the 20th century, the world population increased from 1.5 to 6.1 billion, and according to the latest United Nations (UN) population projections, the world's population will be at 10.9 billion in 2100 (United Nations [UN], 2019). Parallel to this, climate change has become a global worry, and in this regard there has also been an increasing recognition of the profound problems caused by global population growth (Clarke \& Haraway, 2019). Whereas the fertility rates in the so-called Global South remain above the replacement rate, they have been decreasing in many countries around the world in the last three decades (United Nations, 2019). In Europe (49 countries and the Channel Islands), the average fertility rate was 1.61 children per woman in 2019, which is far below the 2.1 replacement level that the UN holds as standard for population regeneration (United Nations, 2019). ${ }^{2}$ In Asia, several countries are facing the same situation, and, as in Europe, they recognise this as a serious problem.

Both Japan and Norway are seen as rather typical examples of their respective regions when it comes to fertility numbers and their evolution in recent years. In Japan, the fertility rate declined from 2.14 in 1973 to 1.74 in 1981, 1.57 in 1989, and 1.36 in 2019 (The Ministry of Health, Labour and Welfare [MHLW], 2020). In Norway, there was a marked decrease in the fertility rates from the mid-1960s to the mid-1980s (from 2.98 in 1964 to 1.66 in 1984) (Ravn, 2005). Whereas the fertility rates continued to fall in most European countries throughout the 1980s and onwards, they started to rise again in the Nordic countries. In 2009, the Norwegian fertility rate was 1.98; however, it has dropped again since then. As can be 


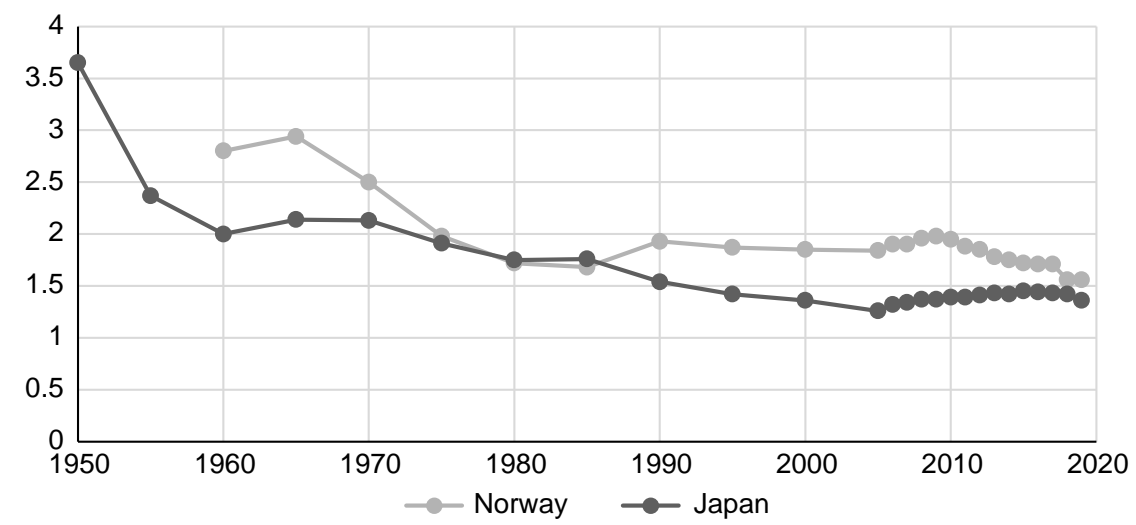

Figure 11.1 Total fertility rates in Japan and Norway.

Note. Source: Japan: IPSS, 'Figure 4-5, Total Fertility Rate of Major Developed Countries: 1950-2018,' Population Statistics of Japan 2020. http://www.ipss.go.jp/syoushika/tohkei/ Popular/P_Detail2020.asp?fname=T03-09.htm Norway: (1960-2008) The World Bank, https://data.worldbank.org/indicator/SP.DYN.TFRT.IN?locations=NO(2009-2019) Statista, https://www.statista.com/statistics/611702/fertility-rate-in-norway/.

seen in Figure 11.1, the actual fertility rate stood at 1.48 in 2020 (Statistics Norway, 2020).

Even though the fertility rate of Japan and Norway are rather similar today, the structural, political, social and cultural factors surrounding them are somewhat different. Despite a decreasing fertility rate, Norway still has a growing population $(0.44 \%$ in 2020$)$, due to immigration and a long history of rather high fertility rates (Statista, 2021a). Japan, on the other hand, has a negative population growth due to limited immigration and a longer history of low fertility $(-2.1 \%$ in 2019) (Statista 2021b). Thus, while both countries are experiencing the phenomenon of an 'ageing population,' it is far more prevalent in Japan.

Intrigued by this complex of similarities and differences, we examine the ways in which national fertility rates, and more specific declining fertility rates, are presented and discusses publicly in the two countries. We pay special attention to what kinds of explanations and measures are launched, and how they relate to and produce specific understandings of gender and nation. We ask: What characterises the public debates about fertility rates in the two countries, and what similarities and differences exist between them?

\section{Theoretical perspectives}

To conceptualise the cultural/public meaning in regard to declining fertility rates and explore the intersections of reproduction, gender and nation, we have found inspiration in Nira Yuval-Davis' theorising of the relationship 
between gender and nation as it unfolds in various kinds of population politics (Yuval-Davis, 1997). According to Yuval-Davis, there are three hegemonic discourses in relation to national reproduction: The 'people as power' discourse, the Malthusian discourse and the eugenics discourse.

The people as power discourse is characterised by the idea that the nation's future depends on continuous population growth, and that this can be ensured both through biological reproduction and through immigration. For women, this way of thinking may mean that, for example, after a natural disaster, war or other crisis, there may be extra pressure for increased reproduction. In this context, not having children can subject women to criticism, but it can also be an effective way of resisting national projects and government policies.

In the second discourse, which Yuval-Davis labelled Malthusian, uncontrolled population growth is understood as a serious societal problem, and responsible policy should be aimed at limiting further growth. This discourse has been criticised for making poor countries and poor people responsible for global problems, and for stimulating and legitimising population politics that are violating peoples,' and in particular women's, reproductive rights (Hartmann, 1995).

The focus of the third discourse, eugenics, promotes population 'quality' over quantity. Quality is achieved through, for example, reward systems that encourage only selected people to have children. Yuval-Davis also notes that eugenics discourse legitimises the use of coercion as a strategy for effecting reproduction. This way of thinking about reproduction and population is highly controversial, and several researchers have shown that eugenic discourses typically are targeting poor women and discouraging them to have more children and thus reproducing power hierarchies (Hartmann, 1995).

\section{Method, data and analytical tools}

The data material consists of white papers, political statements, newspapers and other news media items published in both Japan and Norway between 2013 and 2021. The texts are sampled through systematic searches in national media databases. In Norway, we applied ATEKST, which includes all print and online Norwegian newspapers. In Japan, we used Bunzō II (Asashi Shimbun Database), Yomidas Rekishi-kan (Yomiuri Database Service), Nikkei Telecon (Nikkei Shimbun Database), Maisaku (Mainichi Shimbun Online) and Sankei Shimbun Databases (Sankei Shimbun), which are the databases of the five biggest national newspapers in Japan. In addition, we used news articles that we found through internet searches with keywords. When conducting these database searches, we applied the Norwegian and Japanese terms for population, fertility, fertility rate, reproduction, population politics and declining birth rate. 
We focused on fertility discourse in public media because we see these as integral resources for understandings and meanings in this field (Arnoldi, 2005). Our analysis reveals the kinds of information on fertility confronting the public in both countries as well as the political ambitions integrated in that discourse. We do not see media merely as reproducers of reality, but also as producers. The media is instrumental in defining what is seen as normal, acceptable and aberrant, what deserves and needs special attention, what is taken for granted, and so on. Moreover, media sets the political agenda, and various political actors use media as a vehicle for communication. Thus, we argue that it is important to analyse the ways in which cultural meaning production is represented, developed and formed in and by media.

Our position as researchers in this field is neither that of pro-natalism nor anti-natalism. Rather, we take an explorative approach to the public debates and the meanings expressed there.

\section{Japan: Struggle regarding declining birth rate and strategies to raise fertility rate}

An important area of discussion in regards to the Japanese fertility relates to a narrative of national crisis. On 4 October 2019, Prime Minister Abe made the policy speech at the 200th session on the Diet, and he stated 'we will squarely address the declining birthrate, which should also be called a national crisis [kokunan]' (Abe, 2019). When Abe came to power in 2012, he mentioned that one of his priorities was to increase the number of daycare centres so that mothers can return to the workforce ('Number of newborns,' 2019). However, under the Abe administration, which lasted seven years and eight months, TFR continued to decline every year and reached a record low 1.36 in 2019. It might show that the policy has not been effectively implemented, and it is still hard for young people to balance work, family and childcare while having children. In February 2016, one blog attracted attention in Japanese society. It was the anonymous blog entry posted by a woman who had not been able to get her child into day care facilities. The title was 'My child wasn't accepted for nursery school. Die Japan!!' (Hoikuen ochita Nihon Shine!!) ('Parents protest,' 2016). However, Abe ignored it because it was an anonymous blog post. The entry spread over the Internet, and about 100 parents whose children were refused entry into childcare facilities lunched a protest in front of National Diet Building in Tokyo holding up signs saying 'It was me,' and a website collecting signatures in support of introducing a better childcare system had collected more than 20,000 signatures within a month ('Parents protest,' 2016). The number of children waiting for entry into nursery schools is on decline by the government's childcare support program 'kosodate anshin puran,' however it is still a serious issue in Japan (Hoiku no oshigoto report, 2019). 
Several issues have been identified as leading to a declining birth rate in Japan. In addition to the lack of day-care facilities cited in the blog post above, these include delayed marriage, late-in-life pregnancy, the rising cost of child-rearing and women's increased roles in society and the workplace (Castro-Vázquez, 2017; The Economist Intelligence Unit, 2018).

Cultural value in Japan is given to families comprising a married couple with children. This makes marriage first and foremost a prerequisite for childbearing. However, as scholars have previously noted, women in Japan have become increasingly less likely to get married or bear children in the last decades. This is due to the potential difficulty of maintaining a worklife balance within the traditional gender framework that expects women to prioritise their families (The Economist Intelligence Unit, 2018). In addition, women fear that if they have children outside marriage, they will be socially stigmatised and faced with enormous financial challenges. For example, they typically find themselves in low-paying part-time employment and must live on incomes below the poverty line (Lezott, 2020).

Japan has the highest percentage of the population aged 65 and over in the world. Indeed, as of September 2019, this ageing rate reached a record high of $28.4 \%$. The National Institute of Population and Social Security Research (IPSS) estimated that the rate of population aging will continue to increase, with $30 \%$ and $35.3 \%$ of the population being aged 65 years and over by 2025 and 2040, respectively (Statistics Bureau of Japan, 2019). In general, societies with declining birth rates and ageing populations experience labour shortage, which exerts long-term negative social impacts on the economy (Atoh, 1994). In 2014, the Japanese labour force was 65.87 million, but it is estimated to decrease to 56.83 and 37.95 million by 2030 and 2060, respectively (Cabinet Office, 2018).

MHLW as well as local governments have devised various measures to mitigate the negative consequences of a declining birth rate and to maintain social security. In the 1990s, the Japanese government first initiated and expanded family planning policies and programs that sought to provide monetary assistance directly to parents. This took the form of child allowances and steadily expanded provisions for parental leave and subsidies for childcare services (Tsuya, 2017). In 2010, the government introduced four major policies to support young people's fertility, which centred on pregnancy, childbirth, child-rearing and work-life balance (The Economist Intelligence Unit, 2018).

Among the policy initiatives meant to deal with the declining birth rate, the Japanese government has provided people suffering from infertility with financial and psychological support for taking infertility treatments. The criteria for receiving this support were relaxed first in 2006, then to a greater degree in 2013, making more couples eligible. However, the financial cost of assisted reproductive medicine still overwhelms many infertile couples because the Subsidy for Specific Infertility Treatment Expenses by the government does not cover all financial cost of intrauterine 
insemination, in vitro fertilisation and intracytoplasmic sperm injection. However, in 2020 Prime Minister Suga stated, 'We will swiftly make public health insurance cover infertility treatments and eliminate income thresholds on eligibility. Until such insurance coverage becomes available, we will broadly expand the subsidy measures currently in place.' Furthermore, MHLW sought additional funding from the government in its 2021 budget request to boost subsidies for couples receiving infertility treatments until insurance can cover these treatments ('Itten Toppa,' 2020).

Although the Japanese government has implemented policies intended to support families' fertility and boost the declining birth rate, these polices have failed to produce the desired result. Thus, the fertility rate remains well below replacement levels.

\section{The difficulties of raising children for women in Japan}

Another quite visible area of debate which relates to the Japanese fertility rate is the position of women in society, and, in particular, the difficulties Japanese women face when having children. According to the Japanese National Fertility Survey conducted in 2015, married couples reported that the average number of children they want was 2.32. However, the actual average number of children per family in 2015 was 1.94. IPSS's survey presented the following reasons for them being unable to achieve their desired number of children: 'It costs too much to raise and educate children' (56.3\%), 'I strongly dislike the idea of bearing children at an older age' $(39.8 \%)$, 'I want to have a child but cannot conceive' $(23.5 \%)$, 'I cannot mentally or physically bear the burden of childbearing anymore' (17.6\%), 'I cannot because of health reasons' (16.4\%), 'It would interfere with my job or business' (15.2\%), and 'My house is too small' $(11.3 \%)$ (National Institute of Population and Social Security Research [IPSS], 2017).

The following quotes, derived from newspaper articles, reflect the difficulties Japanese women face when having children. The first three statements show that raising and educating children is extremely expensive:

It costs too much to raise a child. I often hear people around me say that it is impossible for them to raise three children. My husband and I are both full-time employees, but we don't even have a house, so we decided that having only two children is realistic for us. (A woman in her 40s living in Tokyo; ['Fōramu: Tanomuyo,' 2020])

We have a one-year-old child and I am on childcare leave. My husband is a non-regular employee, and the amount of work he receives has been reduced drastically. This has had a serious impact on our household finances. (A woman in her 30s living in Aichi; ['Fōramu: Tanomuyo,' 2020])

Ideally, we would like to have one more child. But I want to respect our son's desire to 'learn,' so we want to be able to pay tuition and academic 
fees in the event that he wants to attend a cram school [private exam tuition] and go to a private high school and university in the future. When we consider education costs, we think, 'We can't afford it for two children.' (A 36-year-old woman living in Fukuoka; ['Fōramu: Tanomuyo,' 2020])

The next statement from a mother shows how difficult it is for women who have small children to get a full-time job in Japan:

I am a non-regular university employee [who does not have maternity benefits]. It is difficult for me to have a second child. If I did have another child, I would have to give up my full-time job for a while. My first pregnancy ended in a premature birth, so I wouldn't be able to work if I get pregnant. We live in a very strange world - I have to choose between a job or a child. (A woman in her 30s living in Tokyo; ['Fōramu: Tanomuyo,' 2020])

The following statement shows that the woman feels guilty towards society and the nation because she chose not to have children at all:

When I hear the words 'declining birth rate,' I feel guilty. I feel like I haven't fulfilled my ultimate responsibility as a human. Naturally, I intended to give birth when I learned that I am pregnant. But at the time of the Lehman shock, there were cases where female colleagues on maternity leave could not return to work. I found it difficult to think positively about having a child. In addition, I didn't want to be bound by the stereotype that 'mothers should be like this.' (A woman in her 40s; [Takahashi, 2018])

On the other hand, the following statement from a father indicates discomfort in choosing the home over work after becoming a parent.

I was busy with work and I often felt guilty when I left work to go home. And I've become more and more frustrated with spending time with my family. Deep down in my heart, I felt that it was natural for me to have a work-oriented life even though I had children. On the other hand, I questioned why my wife didn't reduce her work responsibilities in order to take care of our child, and I was dissatisfied with her. (A man in his 30s; [Takahashi, 2019])

This comment highlights men's role in the fertility decline. Japan has generous paternity leave packages, with one year of paid parental leave available for fathers (with average income, fathers can earn roughly $60 \%$ of their wages during a year-long leave), but today only about $6 \%$ fathers in the private sector take advantage of this benefit. This shows why there was 
so much attention surrounding the decision by the 38-year-old Japanese environment minister, Shinjiro Koizumi, to take two weeks off to care for his newborn baby in 2020. The director of the Research Institute for Women and Careers at Japan Women's University, Machiko Osawa (as cited in Pinsker, 2020), explained the reason for Japanese men's disinterest in paternity leave: 'Taking paternity leave is more likely to reduce promotion possibilities in the future.' This means that to take time off work to care for one's own children is not in line with Japanese cultural norms for manhood.

\section{Psychological pressure on women to procreate}

Whereas Japanese men are publicly given credit for staying home with their children, Japanese women are publicly encouraged to have children and also blamed for not having given birth. According to the Japanese National Fertility Survey conducted in $2015,85.7 \%$ of men and $89.3 \%$ of women between the ages of 18 and 34 who have never been married desire to be married in the future. Moreover, $91.5 \%$ of men and $93.1 \%$ of women from this group desire to have one or more children in the future (National Institute of Population and Social Security Research, 2017). In Japan, women without children often experience social pressure to procreate. Some politicians have made statements criticising women without children for being selfish. In 2003, former Prime Minister Yoshiro Mori (as cited in Hays, 2014) stated,

The government takes care of women who have given birth to a lot of children as a way to thank them for their hard work. (...) It is wrong for women who haven't had a single child to ask for taxpayer money when they get old, after having enjoyed their freedom.

On a similar note, Japan's Deputy Prime Minister Taro Aso (as cited in Jozuka \& Ogura, 2019) stated in 2018, 'There are lots of strange people who blame the elderly for the population crisis, but they are wrong. The problem is with those who haven't given birth.' In 2019, the ex-minister addressed the problem of the nation's shrinking population and encouraged women to 'give birth to at least three children.' These comments outraged many people in Japan, especially feminists; however, there are quite a few people who unconsciously speak heartless words to childless women and couples. According to the survey conducted by Meiji Yasuda Research Institute in 2018, nearly $70 \%$ of married women and $30 \%$ of married men in their late 30 s to early 40 s have experienced harassment due to childlessness. The survey 
result also shows that many childless people feel uncomfortable to live in Japan.

\section{Norway: Between national welfare crisis, patriotism and global climate crisis}

In contrast to Japan, Norway has a comprehensive welfare state which includes a range of generous family policies including state-provisions for pregnancy, birth, extensive schemes for parental leave (including a parental leave designated to fathers), and publicly funded kindergartens and afterschool arrangements (Ellingsæter \& Pedersen, 2016). These policies, however, have not primarily been motivated by pro-natalist objectives but rather by gender equality ideologies and a concern for the general wellbeing of children and their families (Ravn et al., 2016). Moreover, Norwegians have relatively good access to part-time work, which means that parents who cannot or do not wish to work full-time can still earn income. Men's involvement in family life and care work is supported by the state, and this is an important part of the Norwegian model for gender equality, which has been described as dual carer/dual earner model (Ravn et al., 2016).

Despite these generous family policies, which have also been described as 'generous reproductive support' (Skrede, 2004), the average age of first childbirth has increased from under 24 in 1964 to nearly 29.8 in 2019 (Statistics Norway, 2020). Unlike Japan, Norway widely shares liberal social values and is more accepting of cohabiting couples and single people who have children. In 2014, unmarried mothers accounted for $44 \%$ of all births, and single mothers accounted for 13\% (Ellingsæter \& Pedersen, 2016). Still fewer and fewer women become mothers at young age.

\section{The call for more children}

In Norway, as in Japan, the declining fertility rates are overwhelmingly described as a serious problem for the country and its inhabitants' futures. This has been most obvious in recent years, when every new fertility-related measure has been declared 'the lowest one ever measured in the Norwegian context.' The most famous examples of this negative way of framing the declining fertility rate is to be found in Prime Minister Erna Solberg's New Year's speech at the beginning of 2019, where she explicitly asked the citizenry to have more babies:

We Norwegians are having fewer and fewer children. To maintain the population, each of us must have just over two children on average. Today the number is only 1.6. Then there will be relatively fewer young people who will have to bear an increasingly heavy welfare state on their shoulders. Norway needs more children! I do not think I need to explain 
how this is done. I will not make any orders either. Not everyone can have children or wants to have children. For various reasons. And more and more people are waiting longer to have children. Also for various reasons. But if you wait too long, it also becomes more difficult. An everincreasing number of children are now being created with the help of the health service [fertility treatments]. We must therefore ask: Is it too difficult to have children early? We must make good arrangements [for young people] to have children during their studies and early in their careers.

The message conveyed here is pretty clear: The fertility rate is not high enough for the nation of Norway - as we know it - to survive. In her speech, the Prime Minister was also explicit about her main worry, namely the sustainability of a comprehensive welfare state, which is dependent upon a relatively high number of workers and taxpayers. In this way, reproduction was made a question of labour resources and economy, rather than an issue of nationalist ideas about a particular Norwegian community or culture. The speech also provides some information about the problem's diagnosis, as the Prime Minister sees it, namely that the Norwegian population waits too long to have children. She also suggested a possible medicine in the form of political arrangements that will stimulate the population to start their reproductive career earlier in life.

Along a similar vein, other politicians as well as experts and representatives of various organisations have - both before and after this famous speech - expressed worries about the declining fertility rates. This has led to various measures being proposed to solve the problem. The list of suggestions includes increased child benefits, longer paternity leaves and various kinds of bonus for child number three, four and five (Kristensen, 2020). Every now and then, more liberal regulations of assisted reproduction technologies and more state support for using these technologies are also mentioned as relevant measures for increasing the national fertility rate, but only as an addition to the main solution of equal opportunities for parenthood (Stuvøy et al., 2021). However, the overarching question posed in the discussion is, What kind of welfare arrangements can be introduced and/or increased to motivate Norwegian women and men to have more children? The idea that welfare arrangements is an effective measurement is taken for granted; the question is only what exactly should be increased and by how much.

This idea that the state should try to enhance the national fertility rate by introducing various incentives and welfare arrangements represents a new direction in the Norwegian family policy, which up to this point had been presented as gender equality measures rather than pro-natalism. Thus, it is somewhat controversial. This controversy became particularly evident after Prime Minister Solberg's above-quoted speech in 2019, which was met with a lot of attention, including numerous media debates involving politicians, 
experts and lay people. Some debaters took issue with the Prime Minister's position as interfering in people's private lives and trying to put pressure on the younger generation, and in particular on young women. For example, Espen Gamlund (2019), a philosophy professor at the University of Bergen, wrote an opinion piece in a national newspaper with the headline, 'Nine reasons to be sceptical of the Prime Minister's call for more children.' He objected to the Prime Minister interfering in something which 'for the individual is so life-changing and irreversible,' noting that this way of talking about reproduction is 'reducing women into birth machines.' Similarly, Anne Lise Ellingsæter (as cited in Martinčič, 2020), a professor in sociology at the University of Oslo and expert in family policies and fertility rates, expressed it like this:

One can take one step back and ask what role the state should have when it comes to people's reproductive decisions. In my opinion, the Prime Minister's New Year's speech exemplifies that the state is entering people's private sphere when they are asking them to have more children.

\section{Stratifying statements about who should reproduce or not}

Whereas welfare arrangements and family policies are highly pertinent in the political debates about declining fertility rates in Norway, immigration is a more silent issue - at least on the governmental level. In recent years, this silence has somehow been broken, as various debaters have in different fora challenged the strict national focus on fertility rates. For example, the abovementioned Prof. Gamlund (2019) suggested increased international adoption as one alternative to increase the number of children per woman rather that enhancing the birth rate. Others have criticised the government for being double-minded by simultaneously fronting a restrictive immigration policy - which every year rejects the asylum applications of hundreds of children, even those living in very difficult situations in refugee camps - and calling on the nation 'to maintain the population,' as Solberg formulated it. This is how a representative for the Green Party in Norway, Farid Shariati (as cited in Skårderud, 2018), expressed himself to the newspaper Klassekampen when being asked about the prime minister's speech:

One can ask what kind of human view the government has, when they are so concerned with getting women to have more children rather than accepting more immigrants. (...) A better policy, if you want to increase Norway's population, is to be more open to the outside world. We can welcome new people and recognise that they are the most valuable resource available. (...) Norway spends a lot of money that contributes to the flattening of world population growth. 
That's a good thing. But it sends a rather special signal by simultaneously closing the borders for immigration and saying 'there must be more of us.'

But there are also voices sceptical towards these alternative strategies. This reveals that the main concern is not only about numbers, but also the future of the nation and who can and should be birthing the nation - to paraphrase Rodha Ann Kanaaneh (2002). An example showing how this notion can be formulated is to be found in a public statement delivered by Per Willy Amundsen, a representative of the Progress Party (Jensen, 2019): ${ }^{3}$

I think it is important that we have a sustainable population composition. The birth rate among ethnic Norwegians is declining. In line with the Prime Minister, I think it is important to do something about this. But, as I see it, the solution is not to have more immigrants. Quite the contrary we have to make sure that the ethnic Norwegian population is maintained.

Even though Amundsen is known for daring to say what 'common people' are thinking, this eugenics tendency is highly controversial and marginal in the Norwegian context. The fact that his statements have also received negative public reaction is a sign of their marginal status. Having said that, there are several examples of media texts presenting declining fertility numbers among immigrants as positive, which is somewhat paradoxical taking into consideration the call for more babies (Kristensen, 2009, 2020).

\section{Global over-population and national and/or individual responsibilities}

Another strand of discussion in regard to the Norwegian fertility rate is the pressure that the global population growth is putting on the planet, making it reasonable to reduce the number of children everywhere, including in Norway. This argument can typically be found in political claims fronted by the Green Party, experts on climate change and activists engaged in environmental organisations. Spokesperson for the Norwegian Green Party, Rasmus Hansson (as cited in Ekeberg, 2015), highlighted this point:

If they [the government] are actually planning to encourage people to have more children, they are really out of their minds. As I see it, such policies are so outdated, I can hardly believe it. The declining Norwegian fertility numbers are good news. We have to get rid of the idea that everything should increase, and rather start preparing for societies with fewer people. (...) We can't just sit here in rich Norway and claim that the population growth in Africa is the big problem. 
Another example of a statement which questions this idea of increased Norwegian fertility rates is expressed in a national newspaper by 28 -yearold Maja Sørheim (as cited in Salvesen, 2016), a woman who has taken individual moral pride in abstaining from motherhood for the good of the planet: 'Little indicates that the child would have a very good life on a heated and depleted planet. (...) Most important, however, is the fact that having children is equivalent to fuelling the fire further.'

So, even though the fertility rate in Norway is below replacement level, not everyone is sharing the political claim that this is a big problem that should be solved by stimulating the population to have more babies. Quite the contrary, the global population growth and the ways it relates to climate crisis is seen by many to be a much more important problem.

\section{Concluding discussion}

In this chapter we have explored the ways in which national fertility rates, and more specific declining fertility rates, are presented and discussed publicly in Japan and Norway. We have paid special attention to the kinds of explanations and measures that are put forward, and the similarities and differences in this regard that come to play when comparing the two countries. The fertility rates in both Japan and Norway are well below the replacement level, which means that the population will decrease if immigration is not sufficiently high. As our analysis has shown, this decline is seen as a serious problem among leading politicians. Former Prime Minister Abe called the declining birth rate a 'national crisis' at the Diet session in 2019. In the same year, the Norwegian Prime Minister communicated the same message to the Norwegian public by saying, 'Norway needs more children!' Both countries realise the need for countermeasures against the declining birth rate to prevent a future reduction of the labour force, a decline in economic growth and the collapse of the current pension system. However, the interpretations of the crisis and approaches to solving it are different in Japan and Norway. The Japanese government holds an implicit pro-natalist position. Many forms of fertility-related initiatives have been introduced expressly as population policies since the 1990s. The national government as well as the local governments devised various measures, such as monetary assistance in the form of child allowances paid directly to parents, promotion of parental leave, subsidies for childcare services and financial and psychological support for infertile couples. The governments have acted on the belief that the main causes of the declining birth rate are women's delayed marriage and late-in-life pregnancy. However, as this chapter has demonstrated, young people, especially women, expect certain financial and lifestyle difficulties in raising children. In recent years, the Japanese government regards women as an important source of labour and has encouraged them to participate in paid work to make up for labour 
shortage in the society with declining birth rate and ageing populations. However, there is still a strong tendency to regard unpaid work such as child-rearing and housework as women's role in the society. As we introduced in this chapter, Japan has generous paternity leave packages, but today very few fathers take advantage of this benefit. They believe that prioritising housework and childcare over their careers by taking paternity leave is more likely to reduce promotion possibilities in the future.

In comparison to other European countries, women's participation in the labour market in Norway is high, as $83 \%$ of mothers with small children are employed. The extensive schemes for parental leave and publicly funded kindergartens have rendered it possible for women to have a paid job outside the house. The Norwegian government's strategies for increasing fertility are very different from those of the Japanese, as illustrated by the Prime Minister's call for making it easier for young people to have children. In addition, the Norwegian government also pays attention to men's reproductive behaviours and involvement in family life and care work.

On the other hand, in Japan, the rate of births outside of marriage is $2.2 \%$ (Organisation for Economic Cooperation and Development [OECD], 2019). Marriage and childbirth are difficult for the Japanese to consider separately; thus, accepting the idea that women become pregnant while in school and (likely) single is difficult. Instead, the Japanese government has adopted strategies for supporting infertile couples financially and psychologically in order to stop the declining birth rate. However, it has a risk of leading to prejudice against women without children, since a woman's value in society is more likely to be defined according to whether she can give birth. In fact, as we have shown, some politicians have made discriminatory statements against women without children.

Since Norway is already tolerant towards cohabiting unmarried couples, single people and same sex couples, the government provides the same family support to all. Although the Japanese government has given lip-service to the importance of gender equality and initiated some legislation, the rhetoric of many politicians shows that they still have conservative views about marriage, gender roles and childbirth. The Japanese government is also conservative about family formation. It is reluctant to accept diversity and premises its population policies on the traditional nuclear family of heterosexual parents with children. This position puts more burden on women than on men due to the stereotype that women are the main players in housework and childcare.

Immigration is also a factor in both countries. In Norway, immigrants are an important part of the labour force; however, some negative views remain concerning immigrants' fertility. If the national fertility rate continues to decline, immigration will be vital for avoiding a population decline. Even in Japan, society is becoming reliant on immigrant labour. In this regard, it is crucial to consider issues posed by a growing immigrant population within a host society experiencing a declining birth rate. 
A significant difference in the gender gap exists between Japan and Norway. In 2020, the Global Gender Gap Report showed that in the political arena, Norway ranked 3rd out of 156 countries, whereas Japan ranked 120th, and 147th in the political arena. The difference in the gender gap exerts a great impact on the birth policies of the two nations. The fact that Norway's population policies focus on gender equality is a by-product of women's greater participation in working life and political life. In Japan, however, women have little voice in formal politics at the national level, and the employment rate of women is too low. The policies which support working mothers and young couples are not effective enough due to the small number of female politicians and female policy makers, causing the burden on women to increase. In addition, Norway has a better social support system than Japan for all parents and has tried to eliminate genderbased injustice concerning childcare. Seemingly, Norwegian women find work-life balance much easier to achieve than Japanese women do.

Returning to Yuval-Davis' (1997) discourses on fertility and population control, our study finds that the 'people as power discourse' is most prominent in both contexts. It is made particularly explicit through the national leaders' calls for more children. The Malthusian discourse, however, does not appear as relevant for the national context, which is not surprising as the fertility level is extremely low. In Norway, however, the Malthusian discourse does appear in some public discourse, namely when addressing the link of population growth to the climate crisis. The eugenics discourse also features at times, such as when immigrants' fertility rates are discussed. However, for the most part, these perspectives appear as a marginal discourse in Norway compared to the 'people as power' approach.

In any case, the fertility rate is declining not only in Japan but also in Norway. Our analysis indicates that gender equality policies alone are insufficient to mitigate the declining birth rate. Thus, we argue that there is a need for more in-depth research on how young people are experiencing parenthood, and on the roles parenting and family life, including childcare, have in their imaginations of a good and desirable life.

\section{Notes}

1 The term fertility rate refers to the term total fertility rate that represents the number of children that would be born to a woman if she were to live to the end of her childbearing years and bear children in accordance with age-specific fertility rate of the specific year (The Economist Intelligence Unit, 2018).

2 The term replacement level fertility is the fertility rate at which a population is able to replace itself from one generation to the next (Craig, 1994). The Population Division of the United Nations has long used a total fertility of 2.1 children per woman as equivalent to replacement level.

3 A populist party on the far right. 


\section{References}

Abe, S. (2019, 4 October). Policy speech by Prime Minister Shinzo Abe to the 200th [Speech transcription; provisional translation]. Prime Minister of Japan and His Cabinet. https://japan.kantei.go.jp/98_abe/statement/201910/_00003.html

Arnoldi, J. (2005). Medieanalyse og Niklas Luhmanns systemteori [Media analysis and Niklas Luhman's system theories]. In M. Järvinen, \& N. Mik-Meyer (Eds.), Kvalitative metoder i et interaksjonistisk perspektiv [Qualitative methods in an interactionist perspective]. Hans Reizels Forlag.

Atoh, M. (1994). The recent fertility decline in Japan: Change in women's role and status and their policy implications. The population and society of postwar Japan based on half century of surveys on family planning. The Mainichi Newspapers.

Cabinet Office. (2018). Sentaku suru Mirai, Jinkō suikei kara mieru miraizō [The choice for the future: Future image seen from the estimation of population]. [Report]. https:// www5.cao.go.jp/keizai-shimon/kaigi/special/future/sentaku/s2_3.html

Castro-Vázquez, G. (2017). Intimacy and reproduction in contemporary Japan. Routledge.

Clarke, A., \& Haraway, D. (2019). Making Kin not Population. Prickly Paradigm Press.

Craig, J. (1994). Replacement level fertility and future population growth. Population Trends-London, 78, 20-22.

Ekeberg, E. (2015, 17 July). Et miljøproblem [An Environmental Problem]. Klassekampen.

Ellingsæter, A.L., \& Pedersen, E. (2016). Institutional trust: Family policy and fertility in Norway. Social Politics, 1(23), 119-141.

Fōramu: Tanomuyo, Suga Naikaku 2: Kosodate [Forum: Please, Suga Cabinet Part 2: Child Rearing]. (2020, 4 October). Asahi Digital. https://digital.asahi.com/ articles/DA3S14645960.html

Gamlund, E. (2019, 7 January). Ni grunner til skepsis mot statsministerens ønske om flere barn [Nine reasons to be sceptical of the Prime Minister's call for more children]. Aftenposten. https://www.aftenposten.no/meninger/kronikk/i/RxMy9x/ni-grunner-tilskepsis-mot-statsministerens-oenske-om-flere-barn-espe

Hartmann, B. (1995). Reproductive rights and wrongs. The global politics of population controls. South End Press.

Hays, J. (2014). Women in Japan: History, character, customs, advancements and violence. http://factsanddetails.com/japan/cat18/sub118/item627.html

Hoiku no oshigoto report. (2019, 21 March). (2019nen saishinban) Shitte okitai taikijido mondai no genjo to kadai - Genin to Taisaku [(2019 latest version) Current status of issues on waiting list for nursery schools - Causes and countermeasures]. [Report]. https://hoiku-shigoto.com/report/archives/16315/

'Itten Toppa' Funin chiryō josei mo ['One point break through' infertility treatment costs subsidy]. (2020, 24 September). Asahi Digital. https://digital.asahi.com/ articles/DA3S14633037.html

Jozuka, E., \& Ogura, J. (2019, 5 February). Japan's deputy prime minister blames women 'not giving birth' for declining population. CNN. https://edition.cnn.com/201 9/02/04/asia/japan-taro-aso-women-demographics-intl/index.html

Jensen, I. (2019, 10 January). Vil kutte i barnetrygden for at innvandrere skal få forre barn [Want to shorten child benefits to make immigrants have fewer children]. 2Nyheter. https://www.tv2.no/a/10335046/ 
Kanaaneh, R.A. (2002). Birthing the nation: Strategies of Palestinian women in Israel. University of California Press.

Kristensen, G.K. (2020). Offentlige samtaler om fruktbarhet i dagens Norge. Mellom nasjonal velferdsstatskrise og global klimakrise [Public discourses about fertility in contemporary Norway. Between national welfare state crisis and global climate crisis]. Tidsskrift for kjønnsforskning, 44(2). https://www.idunn.no/tfk/2020/02/offentlige_ samtaler_om_fruktbarhet_i_dagens_norge

Kristensen, G.K. (2009). Tobarnskull møter stua full? Innvandreres fødselstall i norsk offentlig diskurs [Two child families meeting families with many children? Immigrants' fertility rate in Norwegian public discourse]. Tidsskrift for kjønnsforskning, 33(4) https://www.idunn.no/tfk/2009/04/art01

Lezott, C. (2020, 29 March). Problems single mothers face in Japan. Zenbird. https://zenbird.media/problems-single-mothers-face-in-japan/

Meiji Yasuda Research Institute. (2018). 25-44 sai no shussann/kosodate ni kansuru chōsa (Survey on childbirth and childcare for Japanese men and women aged 25 to 44 years). [Report]. https://www.myri.co.jp/research/report/pdf/myilw_report_2018_ 03.pdf

The Ministry of Health, Labour and Welfare. (2020). Reiwa gannen (2019) Jinkō doutai toukei (kakutei sū) no gaikyō. [Overview of Vital Statistics 2019]. [Report]. https:// www.mhlw.go.jp/toukei/saikin/hw/jinkou/kakutei19/dl/15_all.pdf

Martinčič, J. (2020, 11 July). Det er et økt press på kvinner om å føde flere barn, ifølge forsker [According to researcher there is an increasing pressure on people to have more children]. Forskning.no. https://forskning.no/barn-og-ungdom-demografi-kilden/deter-et-okt-press-pa-kvinner-om-a-fode-flere-barn-ifolge-forsker/1711055

National Institute of Population and Social Security Research. (2017). Marriage and Childbirth in Japan today: The fifteenth Japanese National Fertility Survey in 2015 - Marriage process and fertility of married couples attitudes toward marriage and family among Japanese singles: Summary of the survey results on married couples/ singles. [Report]. http://www.ipss.go.jp/ps-doukou/e/doukou15/ Nfs15R_summary_eng.pdf

'Number of newborns in Japan fell to record low while population dropped faster than ever in 2018.' (2019, 7 June). The Japan Times. https://www.japantimes. co.jp/news/2019/06/07/national/number-newborns-japan-fell-low-918397-2018government-survey/

Organisation for Economic Cooperation and Development. (2019). SF2.4 Share of births outside of marriage. Family Database in the Asian-Pacific Region. http:// www.oecdkorea.org/resource/download/2019/eng/SF_2_4_Share_births_ outside_marriage.pdf

Parents protest over lack of child care facilities after Abe's weak response to blog post. (2016, $7 \mathrm{March}$ ). The Mainichi. https://mainichi.jp/english/articles/201603 $07 / \mathrm{p} 2 \mathrm{a} / 00 \mathrm{~m} / 0 \mathrm{na} / 011000 \mathrm{c}$

Pinsker, J. (2020, 24 January). Why Icelandic dads take parental leave and Japanese dads don't. The Atlantic. https://www.theatlantic.com/family/archive/2020/01/ japan-paternity-leave-koizumi/605344/

Ravn, M.N. (2005). A matter of free choice? Some structural and cultural influences on the decision to have or not to have children in Norway. In C.B. Douglass (Ed.), Barren states: The population 'implosion' in Europe. Berg Publishers. 
Ravn, M.N., Kristensen, G.K., \& Sørensen, S.Ø. (Eds.). (2016). Reproduksjon, kjønn og likestilling $i$ dagens Norge [Reproduction, gender and gender equality in contemporary Norway]. Fagbokforlaget.

Salvesen, I. (2016, 30 January). Velger klima foran baby [Put the climate before babies]. Dagens Næringsliv.

Skårderud, J. (2018, 7 December). Skal lage barn [Will make children]. Klassekampen. https://klassekampen.no/utgave/2018-12-07/skal-lage-barn

Skrede, K., Ellings'ter, A.L., \& Leira, A. (2004). Familiepolitikkens grense - ved 'likestilling light'? (At the border of family policies - 'equality light'? In: Ellingsæte, A. L. \& Leira, A. Velferdsstatens utfordringer og dilemmaer (The challenges and dilemmaes of the welfare state). Gyldendal akademisk.

Solberg. E. (2019). Statsministerens nyttärstale 2019 [The Prime Minister's annual speech]. Regjeringen.no. https://www.regjeringen.no/no/aktuelt/statsministerensnyttarstale-2019/id2623249/

Statistics Bureau of Japan. (2019). Tōkei kara mita wagakuni no kōreisha, 'Keirō no hi ni chinande [Elderly people in Japan from the viewpoint of statistics: Special edition of Respect-for-Senior-Citizens Day]. Statistics Topic (No. 121). [Report]. https://www.stat.go.jp/data/topics/topi1211.html

Statistics Norway. (2020, 11 March). Births. [Report]. https://www.ssb.no/en/fodte Statista. (2021a). Rate ofpopulation growth in Norway from 2010 to 2020. [Report]. https:/www.statista.com/statistics/587348/population-growth-in-norway/

Statista. (2021b). Japan: Population growth from 2009 to 2019. [Report]. https:// www.statista.com/statistics/270074/population-growth-in-japan/

Stuvøy, I., Kirpichenko, M., Kristensen, G.K., \& Lie, M. (2021). Bioteknologiske fremtider. Refleksjoner over endringer $i$ Bioteknologiloven fra et kjønnsforskningsperspektiv [Biotechnological futures. Reflections over changes in the Biotechnological law from a gender studies perspective]. Tidsskrift for kjønnsforskning.

Takahashi, M. (2018, 30 August). Kazokutte? 'Umu' hen 6: Hoshiku nakatta wakejanai [What is family? 'Giving birth' Series 6: It is not that they don't want to have a child]. Asahi Digital. https://digital.asahi.com/articles/DA3S136564 82.html

Takahashi, K. (2019, 13 July). Chichioya no moyamoya, 'kisha no kokuhaku.' Shigoto to katei no itabasami, kurushii [Father is gloomy, reporter's confession: It is painful to get caught between work and home]. Asahi Digital. https:// digital.asahi.com/articles/DA3S14094674.html

The Economist Intelligence Unit. (2018). Fertile ground: How can Japan raise its fertility rate? The report by The Economist Intelligence Unit. The Economist Intelligence Unit. [Report]. http://www.eiu.com/graphics/marketing/pdf/Fertilityin-Japan-EIU.pdf

Tsuya, N.O. (2017). Low fertility in Japan: No end in sight. Asia Pacific Issues, 131. https://www.eastwestcenter.org/publications/low-fertility-in-japan \%E2\% 80\%94 no-end-in-sight

United Nations. (2019). Total population. World Population Prospect 2019. [Report]. https://population.un.org/wpp/Download/Probabilistic/Population/ Yuval-Davis, N. (1997). Gender \& nation. Sage Publications. 